\title{
Financial Technologies as Drivers of Sustainable Development of Exchange-Traded and Venture Capital Funds
}

\author{
F. S. Parpieva ${ }^{1}$, L. I. Yuzvovich ${ }^{2, *}$, V. E. Frais ${ }^{2}$, Yu. K. Mednikova², E. K. \\ Murzataev $^{3}$ \\ ${ }^{I}$ Osh Technological University named after M.M. Adyshev, Osh, Kyrgystan \\ ${ }^{2}$ Ural State University of Economics, Ekaterinburg, Russia \\ ${ }^{3}$ Eurasian National University named after L. M. Gumilyov, Astana, Kazakhstan \\ *Corresponding author. Email: yuzvovich@bk.ru
}

\begin{abstract}
The present study concludes that the introduction of financial technologies leads to more efficient functioning of the stock market through the use of algorithmic trading in securities of exchange-traded funds. As a result, there is a impetus to invest in venture capital funds (targeting the design of system software support for stock markets during digitalization). Digitalization ensures more efficient functioning of financial markets, free from intermediary and transaction costs. Reducing human interaction in the investment process will result in more dynamic trading, and thereby will reduce the negative impact of human behaviour on investment decisions. Within the framework of the proposed measures to solve problems of infrastructure financing, the most understandable and effective tools of venture capital business have been considered, based on the specifics of the venture capital market.
\end{abstract}

Keywords: financial technologies, digitalization, exchange-traded funds, venture capital funds.

\section{INTRODUCTION}

Exchange-traded funds (ETFs) are, by all accounts, the most innovative financial products that have been introduced to the financial markets over the past few decades [1]. Moreover, they have modified the investment structure to such an extent that passive fund management competes in scale with active fund management. The market share of ETFs in the assets of passively managed mutual funds accounts for $40 \%$ and continues to grow, while passive management tools are estimated control more than $50 \%$ of the US stock market [2]. By the end of 2020, ETF assets in the United States were worth about $\$ 5$ trillion. At the same time, by 2030 this number is predicted to amount to 50 trillion dollars [3]. Significant growth is also expected in the European ETF markets. Against this background, the United States is the undisputed dominant in the global ETF market, as before [4].

The formation of the EFT sector in Russia has coincided with the emergence of various fintech innovations in financial markets. Though these technologies demonstrate significant heterogeneity, some of them interact with passive investment products at several levels. Robo-advisors and algorithmic trading are the innovations that allow developing, and improving the investment process, and ensuring a fast turnover of securities by increasing the securities exchange and eliminating human mediation.

Both the ETF and the fintech markets show a significant breakthrough in the entire global space, since the growth coverage in the US alone is about $\$ 1.5$ trillion [5]. Fintech has a hidden synergetic link with the ETF market, which is characterized by passively managed low-cost financial products that require minimal human intervention. This also means that technological development can cause a feedback effect between Fintech applications and the ETF market.

Venture capital (VC) funding is the 'reverse side of the coin' as compared with ETFs, since there is a counterbalance to riskiness, where $\mathrm{VC}$ funds manage pooled investments in start-ups and are generally characterized as very high-risk opportunities. At the same time, the development of fintech acts as an 
advanced driving force for the development of the VC market during the adaptation to the pandemic outbreak, resulting in a growing demand for high-tech and digital services.

Indeed, the functionality of ETFs depends on the degree of algorithmic traders' activity and arbitrage between ETFs and underlying assets (futures, options and securities). These instruments produce a performance paradigm in financial markets [6]. The conceptual approach to information processing via compression, streaming and acceleration, can be applied to various financial products and technologies, including ETFs and fintech. Along with this, the development of products and applications is a multi-faceted, high-tech process that requires significant investments; thus, it is possible to trace the interdependence between the development of fintech, the growth of the VC market and, as a result, the more rapid development of ETFs through a more adaptive asset management for private investors.

If we consider the adaptation of fintech for ETFs, then when new products emerge, traded assets can be stratified or pooled by agglomerating securities within an index or a stock exchange, which may lead to accelerated investment by tracking the relevant benchmarks. Algorithmic trading and robo-advisors could enhance the diversity of models used in trading financial assets [7].

The described technologies can also have an impact of a qualitative shift to information processing in financial markets, at a time when trading is becoming more dynamic and augmented with passive investment strategies. Data digitalization creates the effect of automation.

The most common fintech tools that affect the development of ETFs are robo-advisors and algorithmic trading; they are the outcomes of global digitalization, which is $70 \%$-backed up by $\mathrm{VC}$ [8].

The key benefits of global digitalization include decentralization and diversification, higher degree of transparency, better access to and convenience of financial services for retailers and professional securities market players [9].

As a result, a growing level of automation and software applications in investment activities is the result of the global transition to digital technologies and fintech products. Despite the fact that these benefits are considered as a driver of development, they have some shortcomings such as correlation of investments, an increasing number of passive investment structures resulting from impulse trading that lacks research and analysis.

\section{METHODS AND MATERIALS}

In the context of investment consultancy, roboadvisors can receive the investor's personal data and measure their risk appétit from questionnaires. This information allows the robo-advisor to build an investment portfolio by applying an algorithm of investment actions, which involves the use of preprogrammed computerized instructions. Thus, investment advice is largely automated with limited personal interaction. It is worth noting that roboadvisors often channel customers' funds into ETFs.

At the macro level, the introduction of digitalization ensures more efficient functioning of financial markets, free from intermediary and transaction costs. By reducing human involvement in the investment process, it is worth noting a more intensive trading, and thereby a less negative impact of human behaviour on investment decisions. Algorithmic trading is the main driver of growing trading in securities.

The logic of the present study is built on the development of ETFs along with $\mathrm{VC}$ funds in order to illustrate the process of $\mathrm{VC}$ funding in the era of digitalization and globalization. The organizational models of VC management companies during a crisis are considered. A pool of major players has formed at the current stage of the global VC market development, (Table 1).

Table 1. Major types of VC market investors [10]

\begin{tabular}{|c|c|l|}
\hline $\begin{array}{c}\text { Investor } \\
\text { type }\end{array}$ & $\begin{array}{c}\text { Capital } \\
\text { invested }\end{array}$ & \multicolumn{1}{|c|}{ Description } \\
\hline $\begin{array}{c}\text { Business } \\
\text { angels }\end{array}$ & $\begin{array}{c}\text { Up to } \\
\$ 10 \\
\text { million }\end{array}$ & $\begin{array}{l}\text { Independent individuals who invest } \\
\text { their own money in start-ups and } \\
\text { other early-stage businesses }\end{array}$ \\
\hline $\begin{array}{c}\text { Business } \\
\text { incubators }\end{array}$ & $\begin{array}{c}\text { Up to } \\
\text { million }\end{array}$ & $\begin{array}{l}\text { Organizations that help start-up } \\
\text { companies develop their business by } \\
\text { providing a full-scale range of } \\
\text { services starting with management } \\
\text { training and office space and ending } \\
\text { with VC ind }\end{array}$ \\
\hline $\begin{array}{c}\text { Venture } \\
\text { capital } \\
\text { funds }\end{array}$ & $\begin{array}{l}\text { Up to } \$ 1 \\
\text { billion }\end{array}$ & $\begin{array}{l}\text { Legal entities pooling investments } \\
\text { from individual investors, } \\
\text { institutional investors } \\
\text { governments that seek to invest in } \\
\text { innovative projects. VC funds play } \\
\text { an active and hands-on role in the } \\
\text { management and operations of the } \\
\text { business through a management } \\
\text { company that includes professional } \\
\text { economists and analysts }\end{array}$ \\
\hline
\end{tabular}

There are two main types of VC funds.

1. A self-liquidating fund can be established as a limited liability partnership for a limited period [11]. Within the framework of this structure, a group of investors undertakes to deposit a certain amount of money prescribed in the investment agreement for the period of the fund existence. The 
funds are collected in the proportion to investors' commitments (capital call) as the need arises for investing and covering fund management expenses.

2. An evergreen fund. Its main difference from a selfliquidating fund is to reinvest received profit in new projects. At the same time, the investment memorandum remains valid. The date of fund liquidation is agreed in advance or is conditioned by a liquidation intention, declared by investors.

The investment activity of companies managing selfliquidating funds of the 'closed' type is regulated by a clear organizational model. The management company (partners) raises finance by collecting investors' commitments to invest in the fund. To do this, investors are presented with an investment memorandum, which clearly states the scope of investment, the duration of the investment period, the minimum and maximum amount of investment per project, organizational expenses, remuneration based on the fund's performance results and other important issues. After the investors' obligations are collected, the fund is 'closed' to external investors. Then, the management company starts its activities by investing the fund's money in innovative projects, following the investment memorandum articles. It is important to emphasize that in a traditional fund organizational expenses can be covered during the investment period only. As a rule, the investment period comprises from 30 to $50 \%$ of the total 'lifetime' of the fund. However, the management company has to pay to investment analysts regularly, for them to evaluate projects in terms of potential disposal, or 'exit'. In this regard, the management company has to constantly raise funds in order to ensure fixed costs coverage [12].

Thus, the main aspect of this organizational model is as follows: at a certain stage fixed costs of a $\mathrm{VC}$ fund are covered at the expense of future obligations to investors. Management companies are forced to start new funds to pay for infrastructure throughout the entire period of the fund performance.

The study is based on the data collected through the PitchBook platform, one of the best providers of private market database. This platform offers digital products and financial technologies, thus forming Big Data that cover the VC market, private markets, and the market of mergers and acquisitions. In 2020 VC investments totalled $\$ 277.9$ billion. The share of VC-based funds exceeded $68 \%$, and of the 'closed' type - 95\% [13].

\section{RESULTS AND DISCUSSION}

According to the statistics, an average fund is committed for 10 - 15 years [14]. However, there are 'shorter' funds, with 6 - 8 years' commitments. Thus, in order to maintain infrastructure throughout the fund's life cycle, the management company is forced to undertake new long-term obligations by starting a new fund.

Getting beyond this organizational model is quite difficult. The advantages of its application are based on the fact that during the fund life cycle, investors do not have a right to repudiate their obligations to the management company. Also, due to collected pool of funds, the main indicators are calculated, namely: organizational expenses, which make up an average 1$2 \%$ of the funding; dry powder (the amount of cash reserves or liquid assets available for use, kept on hand in order to take advantage of private equity investments that may present themselves for immediate funding) and other significant indicators. All this ultimately creates a clear cash flow, which allows developing a spending strategy, which is one of the priority financial metrics of the fund [15].

In an effort to invest more raised funds, the management company also strives to reduce spending on infrastructure, since the key partners of the fund receive carried interest - a share of fund's profits that may account to around $20 \%$ of the fund's annual profit. The payroll budget for investment analysts, marketers, and economists becomes a priority. Within the framework of financial policy, the most feasible solution to this problem is a deliberate increase in the share of organizational expenses prescribed in the investment memorandum [16]. However, by raising this indicator from $1-2 \%$ of the total value of the fund to $3-$ $4 \%$, the fund may lose part of the invested finance. For big players of the VC market, e.g. Andreessen Horowitz, Sequoia Capital, DST Global, with raising capital worth over $\$ 1$ billion, this type of expenditure is absorbed by balancing the payroll budget on the basis of average rates on the labour market. For funds with the capital from $\$ 20$ to $\$ 240$ million, infrastructure spending impacts the key costs of the management company needed for the implementation of direct functionality [17].

One of the possible alternatives to the model that ensures financing the infrastructure of the management company at the expense of funds attracted to new funds is to attract borrowings to the management company after the fund's investment period is over. As a rule, when the fund has fully formed its portfolio, part of the finance exists as dry powder only, i.e. as reserves for possible additional investment in portfolio companies. Thus, the presence of resources for additional investment, but lack of capital for infrastructure maintenance, gives the management company a chance to borrow from key investors of the established fund, both as convertible notes and as a bond issue. These types of borrowings allow the management company to have better conditions and eliminate the need for new external investors [18]. 
Given the organizational structure of the management company, which might be similar to start ups, at the stages of fund raising, investment and before meeting all obligations, the management company makes no profit. In this context, it is possible to forecast carried interest which is meant to cover loan payment. In the case of convertible notes, based on the results of the management company's performance, the loan may be converted into shares. Thus, investors have the right to claim a proportion of the management company's income either as a monetary compensation or as equity capital. The terms of converting a loan into shares can be considered by the parties when closing settlements with investors as part of the fund's liquidation process.

The key advantages of convertible notes in the original model are as follows:

1. Quick transfer of funds to ensure the continuous performance of the management company;

2. Absence of time, labour, and financial costs associated with the need to redistribute the share in the authorized capital of the management company;

3. Hedging the management company's risks caused by the loss of some potential income from investment activities based on the IRR of a specific fund;

4. Hedging the investors' risks caused by possible difficulties in mutual settlements based on the fund performance, since the possibility of conversion into capital stock of the management company is being considered.

In the case of convertible notes the focus is on the interest rate, discounts, conversion cap, or the company's valuation limit (the limit of the management company's performance) at which the conversion takes place; maturity, or when the loan is due; maturity cap, or the projected results of the management company performance. The most important factor is that the use of convertible notes speeds fund raising. Based on the results of the fund's performance, the management company shares part of its profit and thus meets all parties' obligations.

The second option for financing the infrastructure of the management company in the fund's post-investment period is to issue corporate bonds with a maturity tailored to the results of the fund's performance when settling investment obligations [20]. These are corporate, convertible, discount, long-term bonds. They are issued in the currency of the fund's capital (the share of which in fixed assets is at least $50 \%$ of the total capital or liabilities). Bonds offer carried interest and have limited circulation.

These bond characteristics ensure the best terms for both the lender and the management company. Thus, with borrowings, the management company receives resources to finance organizational costs in the postinvestment period. At the same time, more raised capital may be invested in innovative businesses, and therefore, a higher carried interest tailored to the fund's performance becomes a priority task for the management company.

Having analyzed the information about VC funds, it is worth noting that $\mathrm{VC}$ investments are negatively affected on a global scale, since economic uncertainties and the impact of non-economic factors have prompted investors to retreat in the short term. The economic downturn in China and lengthy Brexit, trade wars between the US and other regions also have served as a negative impact factor [12].

However, using financial technologies, European countries have been able to maintain the sustainability of VC investment. Local uncertainties such as Brexit has not significantly affected the entire European VC market, as there has been growth in indexes of ETFs and IT companies, due to the introduction of new technologies: e-mobility charging (OVO Energy, UK), biotechnologies (Arvelle Therapeutics, Switzerland), farmer start-ups (Ynsect, France) [21].

Analyzing the impact of various factors on the structural changes and competitive environment in the $\mathrm{VC}$ and ETF market, it is worth noting that financial technologies are the driving force of sustainable development. Digitalization of the process and financial technologies make it possible to enlarge the range of investment targets. Automated trading on the stock market will help to avoid or reduce the risk of a systemic crisis, while enhancing the growth of the $\mathrm{VC}$ funds sector, and subsequently will give an impetus to the development of ETFs.

The evolution of different forms of fintech entails the introduction of rapid strategies in applications and other services, which on the one hand, allows to optimize and simplify the process of investing into ETFs; on the other hand, to reduce risks of $\mathrm{VC}$ investment.

\section{CONCLUSION}

To sum up. It is important to note that the organizational model of the fund management company has similarities with the start-up model. The answer to the question "Why is it so important for the management company to settle all obligations, including those related to infrastructure?" is that the VC market is constantly changing. It has shown the ability to actively resist crisis situations and proved to be quite stable, which has raised interest from more investors. Given the specifics of VC business, it is also essential for investment funds to stay informed, adopt business development strategies proposed in innovative projects, and use alternative opportunities to solve challenges of 
VC management. Within the framework of the proposed solutions related to infrastructure financing, no new organizational structures or financial models have been proposed, however, the most understandable and effective market tools have been looked upon through the specifics of the VC market. In terms of ETFs, the present study provides the foundation for digital transformation of ETFs in Russia, where financial technologies act as one of the drivers of the stock market development and implementation of the investment strategy in this financial instrument.

\section{REFERENCES}

[1] L. Yuzvovich, V. Frais, G. Kodasheva. Exchangetraded mutual investment funds as a driver of stock Market Development in terms of profitability and alternatives. In: SHS web-conferences, of the 3rd International Scientific Conference on New Industrialization and Digitalization (nid 2020), Yekaterinburg, Russian Federation, December 12, 93, $2020 . \quad$ DOI: https://doi.org/10.1051/shsconf/20219302027.

[2] J. Cox, Passive investing automatically tracking indexes now controls nearly half the US stock market (14 March 2019).

[3] C. Reinicke, The ETF market will hit $\$ 50$ trillion by 2030. Bank of America says.

[4] V. Frais, L. Yuzvovich, Formation of the exchange policy of mutual investment funds in Russia. In: Financial Economics, 7 (2020).

[5] Venture pulse Q1 2020. Global analisys of venture funding. In: KPMG Enterprise. https://assets.kpmg/content/dam/kpmg/xx/pdf/2019 /04/venture-pulse-q1-2019.pdf.

[6] Venture investments in Russia. https://www.tadviser.ru/a/375091.

[7] Financial Stability Board, Financial Stability Implications from FinTech: Supervisory and Regulatory Issues that Merit Authorities Attention (June 2017). https://www.fsb.org/wpcontent/uploads/R270617.pdf.

[8] PitchBook. Database. https://pitchbook.com/data.

[9] Rebelsky N. M. Closed unit investment fund as a form of venture financing. In: Securities, 9 (2011) pp. 13-14.

[10] Venture Pulse Q2 2020. Global analysis of venture funding. In: KPMG Enterprise. https://home.kpmg/xx/en/home/campaigns/2019/07 /q2-venture-pulse-report-global.html.

[11] Venture pulse Q3 2020. Global analisys of venture funding. In: KPMG Enterprise. https://home.kpmg/xx/en/home/campaigns/2019/10 /q3-venture-pulse-report-global.html.

[12] Venture pulse Q4 2020. Global analisys of venture funding. In: KPMG Enterprise. https://home.kpmg/xx/en/home/campaigns/2020/01 /q4-venture-pulse-report-global.html.

[13] PWC.

Database. https://www.pwc.com/us/en/industries/technology/ moneytree.

[14] The innovation policy platform. http://www.innovationpolicyplatform.org.

[15] Omarova S. T, New Tech v New Deal. In: Fintech as a Systemic Phenomenon, 36 (2019) pp. 735-787.

[16] Financial Stability Board, Financial Stability Implications from FinTech: Supervisory and Regulatory Issues that Merit Authorities Attention (June 2017). https://www.fsb.org/wpcontent/uploads/R270617.pdf.

[17] D.A. Ishchenko, Prospects for the development of venture capital investment in Russia in the face of modern macroeconomic risks. In: Norwegian Journal of Development of the International Science, 27-2 (2019) pp. 51-58.

[18] RVC. A strategy for the development of the venture capital investment industry in the Russian Federation.

https://www.rvc.ru/upload/iblock/11d/RVC vc_strat_draft.pdf.

[19] D.V. Udulova. Trends in the development of venture capital investment in Russia. In: Izvestia SPbMEU, 4(124) (2020) pp. 32-40.

[20] A. Berman, M. Cano-Kollmann, R. Mudambi. Innovation and entrepreneurial ecosystems: fintech in the financial services industry. In: Review of Managerial Science, 2021. 